University for Business and Technology in Kosovo

UBT Knowledge Center

UBT International Conference

2017 UBT International Conference

Oct 29th, 5:00 PM - 5:15 PM

\title{
Dilemmas about the core values in the European Union
}

Elisabeth Kardos Kaponyi

Corvinus University, e.kaponyi@uni-corvinus.hu

Follow this and additional works at: https://knowledgecenter.ubt-uni.net/conference

Part of the International Relations Commons

\section{Recommended Citation}

Kaponyi, Elisabeth Kardos, "Dilemmas about the core values in the European Union" (2017). UBT International Conference. 317.

https://knowledgecenter.ubt-uni.net/conference/2017/all-events/317

This Event is brought to you for free and open access by the Publication and Journals at UBT Knowledge Center. It has been accepted for inclusion in UBT International Conference by an authorized administrator of UBT Knowledge Center. For more information, please contact knowledge.center@ubt-uni.net. 


\title{
Dilemmas about the protection the core values in the European Union
}

\author{
Elisabeth Kardos Kaponyi ${ }^{1}$ \\ Faculty of Social Sciences and International Relations of Corvinus University of \\ Budapest \\ e.kaponyi@uni-corvinus.hu
}

\begin{abstract}
The European integration was primarily about economic cooperation, but the European Union's role in protecting the core values in its Member States. EU values were first mentioned in the 1992 Maastricht Treaty on European Union, and since the Amsterdam Treaty the community law has a sufficiently precise description of this values, which should be respected not only by countries aspiring to the EU but also by the Member States themselves. The Lisbon Treaty defines EU values; however, nowadays the EU has to face the phenomenon when some government apparently violate these values. In recent years, defiance of core EU principles by the Polish and Hungarian governments is turning into a political debate. The European Commission has taken legal action against both governments, and the European Parliament supports this course. This short paper would like to address what the European institutions can do in these cases. Is the current treaty of the EU effective to address these phenomena?
\end{abstract}

Keywords: European Union, European integration, economic cooperation

\section{Some specific features of the European Union}

The European Communities (EEC)179was originally created as an international organisation with an essentially economic scope of action, in accordance with Article 3 of the Rome Treaty. 180The community of states that Europeans have created was globally unique and goes against the so-called Westphalian model of states. Sovereignty, as a concept, formed the cornerstone of the edifice of international relations that 1648 raised up. Sovereignty was the crucial element in the peace treaties of Westphalia, which enthroned and sanctified sovereigns, gave them powers domestically and

${ }^{179}$ Due to the Maastricht Treaty (1993) the name has changed to European Community (EC) and European Union (EU).

${ }^{180}$ Throughout its history, the European Union (EU) has been gradually expanding. The EU is currently made up of 28 countries. Intergovernmental treaties between the Member States created the EU. These treaties defined a number of institutions, and defined their competence. See: R H. Folsom: European Union law in a nutshell, St. Paul, MN: West Academic Publishing, 2014. 
independence externally.181 In the framework of the European integration, the Member States, have limited their sovereign rights in a number of fields on a voluntary basis and are thus bound to apply the European community law and the legal decisions of the European Court of Justice (hereinafter: ECJ) as an integral part of their national legal system.182According to the famous ruling Van Gend En Loos of the EJC “...[T]he European Economic Community constitutes a new legal order of international law for the benefit of which the states have limited their sovereign rights, albeit within limited fields, and the subjects of which comprise not only the Member States but also their nationals.183In practice, the Member States, signing the Treaties, have surrendered their sovereignty in order to belong to the EU. In some cases the Member States, as sovereign actors can use veto to prevent an EU's decisions, but the extension of qualified majority voting forces the Member States to find allies and reach compromises.184As it has recently been noted, this limitation on the sovereign rights of the Member States is working on a voluntary basis, and these rights also means that they could freely decide to joint to the EU, or revoke their membership from this organisation.185Although the voluntary limitation of sovereignty is a clearly declared fact, there are different approaches to sovereignty from the perspective of the Member States. One hand the countries that joined in 2004 and 2007, which were not very keen on surrendering their recently regained sovereignty to the EU, other hand the sovereignty-friendly countries like Denmark, France, and the United Kingdom that insisted on keeping the EU out of national governance. It may be noted that in the background of Brexit, the idea of sovereignty, namely that 'the EU threatens British sovereignty' has also been strongly illustrated.186. This issue is closely related to the principle of conferral, which clearly indicates that restriction of the sovereignty is limited to achieving a specific purpose described in the Treaties.187 Under the principle of conferral, the

\section{${ }^{181}$ SEE: DEREK CROXTON: THE PEACE OF WESTPHALIA OF 1648 AND THE ORIGINS OF SOVEREIGNTY, THE INTERNATIONAL HISTORY REVIEW,} VOLUME 21, 1999

${ }^{182}$ The concept of sovereignty is a difficult notion to assess. There are a variety of sovereignty theories, with which the author does not intend to deal with. One of the basic works, a classical analysis of the topic is: Krasner, Stephen D. (1999): Sovereignty: Organized Hypocrisy. Princeton, NJ: Princeton University

${ }^{183}$ Case 26/62 Van Gend En Loos v Administratie Der Belastingen [1963] ECR

${ }^{184}$ Qualified majority is the most widely used voting method in the Council. It's used when the Council takes decisions during the ordinary legislative procedure, also known as co-decision. About $80 \%$ of all EU legislation is adopted with this procedure. From November 2014, a qualified majority is reached if two conditions are met: $55 \%$ of Member States vote in favour - in practice this means 16 out of 28 and the proposal is supported by Member States representing at least $65 \%$ of the total EU population. This procedure is also known as the 'double majority' rule.

${ }^{185}$ Article 50 of the Treaty of Lisbon gives any EU Member State the right to quit unilaterally, and outlines the procedure for doing so. It gives the leaving country two years to negotiate an exit deal and once it's set in motion it can't be stopped except by unanimous consent of all Member States.

${ }^{186} \mathrm{~A}$ referendum - a vote in which everyone (or nearly everyone) of voting age can take part - was held on Thursday 23 June, 2016, to decide whether the UK should leave or remain in the European Union. Leave won by $51.9 \%$ to $48.1 \%$. The referendum turnout was $71.8 \%$, with more than 30 million people voting.

${ }^{187}$ Consolidated Version of the Treaty on European Union, Title I Common ProvisionsArticle 4, Official Journal of the European Union C 326/1 26.10.2012. 
Union shall act only within the limits of the competences conferred upon it by the Member States in the Treaties to attain the objectives set out therein. Competences not conferred upon the Union in the Treaties remain with the Member States.188 In an oft-quoted statement (Costa v ENEL case), the ECJ made it clear that "...[B]y creating a community of unlimited duration, having its own institutions, its own personality, its own legal capacity and capacity of representation on the international plane and, more particularly, real powers stemming from a limitation of sovereignty or a transfer of powers from the states to the community, the member states have limited their sovereign rights and have thus created a body of law which binds both their nationals and themselves."189The exercise of Union competencies also governed by the principles of subsidiary and proportionality and Protocol No. 2 of the Lisbon Treaty, which is annexed to the Treaties, incorporates an 'early-warning' system involving national parliaments in the monitoring of how subsidiary is applied.190 It should be pointed out, that under the Lisbon Treaty, the previous limitations of the sovereignty upon the Member States are according to the ruling of the ECJ, namely the Lisbon Treaty reinforced that the community law is an independent source of law, it may not be overridden by domestic legal provisions, and a contrary view would undermine the EU's character and affect its ability to achieve its objectives. This shows that the key feature that makes the EU different in kind from every other international organisation to which a country belong, is the European community law, particularly the principle of supremacy. Nowhere in the Treaty is there a reference to the supremacy of the EU law; however, the ECJ has consistently held that this principle of supremacy is implied in the Treaty. The Court addressed this issue of supremacy in the above mentioned ruling Costa $v$ ENEL, stipulating that contrast with ordinary international treaties, the ECC treaty has created its own legal system which, on the entry into force of the treaty, became an integral part of the legal systems of the Member States and which their courts are bound to apply.191Moreover, “...[t]he law stemming from the treaty, an independent source of law, could not because of its special and original nature, be overridden by domestic legal provisions, however framed, without being deprived of its character as community law and without the legal basis of the community itself being called into question."192Consequently, all law that stems from the Treaty must be adhered to by the Member State through national law. Although the supremacy has never been explicitly set out within a Treaty when the Lisbon Treaty came into force on 1 December 2009, its Declaration 17 stated as follows: “...[T]he Conference recalls that, in accordance with well settled case law of the Court of Justice of the European Union, the Treaties and the law adopted by the Union on the basis of the Treaties have primacy over the law of Member States, under the conditions laid down by the said case law."193The Conference also decided to attach as an Annex

\footnotetext{
${ }^{188}$ Ibid.

${ }^{189}$ Case 6/64 Flaminio Costa v ENEL( (Ente Nazionale Energia Elettrica) [1964] ECR 585 (6/64) http://eur-lex.europa.eu/legal-content/EN [12-09-2017] Permanent limitation of the sovereign rights of Member States

190 National parliaments are informed of all new legislative initiatives and if at least one-third of them are of the view that a proposal infringes the principles of subsidiarity, the Commission will have to reconsider the proposal.

Consolidated Version of the Treaty on European Union, Title I CommonProvisionsArticle 5(1), Official Journal of the European Union C 326/1 26.10.2012.

${ }^{191}$ Ibid.Community legal system - special character

${ }^{192}$ Ibid. Community legal system - Position in relation to national legal systems

${ }^{193}$ Consolidated version of the Treaty on the Functioning of the European Union - Declarations annexed to the Final Act of the Intergovernmental Conference which adopted the Treaty of Lisbon, signed on 13 December 2007 - 17. Declaration concerning primacy
} 
to the Final Act the Opinion of the Council Legal Service on the primacy of EC law as set out in $11197 / 07.194$ Nevertheless, the supremacy is not explicitly declared in the Treaties, it is clearly enshrined in the Accession Treaties. E.g. Accession Treaty of Croatia stipulated that “... [I]n joining the European Union, Croatia accepts, without reserve, the Treaty on European Union[...] It is an essential feature of the legal order introduced by these Treaties that certain of their provisions and certain acts adopted by the institutions are directly applicable, that the law of the Union takes precedence over any national provisions which might conflict with it, and that procedures exist for ensuring the uniform interpretation of the law of the Union. Accession to the European Union implies recognition of the binding nature of these rules, observance of which is indispensable to guarantee the effectiveness and unity of the law of the Union."195

It is important to consider not only the member States have to respect the common rules of the Union, but also the Union shall respect the equality of Member States before the Treaties as well as their national identities, inherent in their fundamental structures, political and constitutional, inclusive of regional and local self-government. It shall respect their essential State functions, including ensuring the territorial integrity of the State, maintaining law and order and safeguarding national security. In particular, national security remains the sole responsibility of each Member State. ${ }^{196}$ In view of the above, there is, on the one hand, a single set of requirements, which the Treaties and the EJC stipulated for Member States; on the other hand, there are a set of obligations of the Union, respecting the national identities, fundamental structures, political and constitutional order of the Member States.The Union and its Member States are interdependent in multiple areas, the European Union is a complex system based on mutual trust, which represents a delicate balance of the competencies between the EU and the Member States. As competences are not always well and satisfactorily circumscribed, disputes over interpretation of the rules often arise. As European integration expanded, the scope of these debates increased. Concerning the protection of the core values of the Union, most of the political debates are about whether the EU properly exercises its powers, whether it sufficiently respects the competences of the Member Statesaccording to the Treaties? In practice, the EU can not only intervene to protect its constitutional core, but it is also unequivocally obliged by the Treaties to act. ${ }^{197}$ Typically, on issues

194 "It results from the case-law of the Court of Justice that primacy of EC law is a cornerstone principle of Community law. According to the Court, this principle is inherent to the specific nature of the European Community. At the time of the first judgment of this established case law (Costa/ENEL, 15 July 1964, Case 6/641 there was no mention of primacy in the treaty. It is still the case today. The fact that the principle of primacy will not be included in the future treaty shall not in any way change the existence of the principle and the existing case-law of the Court of Justice." (JUR 260)

https://www.cvce.eu/en/obj/opinion_of_the_legal_service[14-09-2017]

${ }^{195}$ Commission Opinion of 12 October 2011 on the application for accession to the European Union by the Republic of Croatia Official Journal of the European UnionVolume 55, 24 April 2012, L 112/3 Art. (8)-(9)

http://eur-lex.europa.eu/legal-content/EN/[12-09-2017]

${ }^{196}$ Ibid. Art.5.

197 Petra BÁRD, Sergio CARRERA, Elspeth GuILD and Dimitry KochENOV with thematic contribution by Wim MARNEFFE: An EU mechanism on Democracy, the Rule of Law and Fundamental Rights, 
affecting the internal market, the Commission and the ECJ's best practices are able to handle disputed issues through the informal pilot procedures ${ }^{198}$ and by the formal infringement procedures. ${ }^{199}$ Finally, the ECJ can rule definitively that a breach of EU law has occurred. However, in the questions that are related to the compliance with the enforcement of the rule of law and human rights principles dispute settlement is quite cumbersome.

\section{The European Union as a community of values}

It is a positive fact that the European Union has always been more than a mere economic union; the European Union is understood as a community based on common values. ${ }^{200}$ Thefirstquestionthatneeds to be clarified, is there any difference betweenEuropean values andvalues of the European Union? It can be statedthat virtually there is nofundamental differencebetween the two phenomena.Basically,onlythe European regionalorganizations'statuteshavereferences tothese values, namely, the Council of

No. 91 / April 2016, In. CEPS Papers in Liberty and Security in Europe, p. 73. CEPS website (www.ceps.eu)

${ }^{198}$ The idea for the EU Pilot project was launched in the Commission Communication in 2007 on 'A Europe of results' (COM(2007)502).EU Pilot is an informal dialogue between the Commission and the Member State concerned on issues related to potential non-compliance with EU law, prior to launching a formal infringement procedure. EU Pilot system aims at decreasing the number of formal infringement cases against Member States and referrals to the ECJ, instead the Commission works together with a Member State to find an effective way of application of the EU rules.Using EU Pilot, it sends a query to the national government concerned, which has 10 weeks to reply. The Commission then has 10 weeks to assess the response.If the response is unsatisfactory, the Commission may start infringement proceedings. By now, all 28 EU Member States are taking part in EU Pilot.

${ }^{199}$ In accordance with Article 258 of the Treaty on the Functioning of the European Union (TFEU) the Commission may start 'infringement proceedings' if it considers that e.g. a Member State has not transposed an EU directive correctly or on time, or is applying single market rules incorrectly. If an EU county fails to communicate measures that implement the provisions of a directive in time, the Commission may ask the Court to impose penalties.If the Court finds that a country has breached EU law, the national authorities must take action to comply with the Court judgment. If the Member State fails to comply with Court's judgment, the Commission may, after sending a further letter of formal notice and reasoned opinion, bring the matter before the Court of Justice a second time, seeking the imposition of a penalty payment under Article 260 of the TFEU.

http://ec.europa.eu/internal_market/scoreboard/performance_by_governance_tool/infringe ments/index_en.htm [24-09-2017]

See more: Stine Andersen: The Enforcement of EU Law: The Role of the European Commission, OUP Oxford, 2012

${ }^{200}$ Common European values and identity task force, Lisbon executive summary

http://tt.europeanideasnetwork.com/index[27-09- 2017] 
Europe, the EuropeanUnion and the OSCE, which rely on political dialogue about shared values with governments, civil society and the other stakeholders. The scopes of the these institutions are different; the question is rather how could the so-called European values be enforced and protected by the European institutions in particular by the EuropeanUnion?

The main objectives of the Union are now to promote peace, the Union's values and the well-being of its peoples. It is very important for the people who live in the European Union to realise that the Union has been built on common values. The European Union declared in many ways that the EU is a community of shared values; freedom, democracy, equality, the rule of law and respect for human rights included the inviolability of human dignity, the right to life and the prohibition of the death penalty, the right to integrity and the prohibition of torture, freedom of thought, conscience and religion and much more.

When considering the basic characteristics of European values, we can attempt to identify elements of the broad philosophical notion of these values. European values can be described as a complex set of virtues. Such things as European values are rather than simply western or universal values, held by people in many other parts of the world, but there are some differences are also observed. The European values are typically human-rights sensitive, social, secular and liberal; prefer the idea of a rules-based system of global governance, and strong international institutions. In the most general sense European core values are freedom, equality, democracy, the rule of law; respect for human rights.

First of all, mention should be made to the rule of law, because respect for the rule of law is of particular importance within the EU, it is in many ways a prerequisite for the protection of all other fundamental values of the Union and for upholding all rights and obligations deriving from the Treaties and from international law.

The modern concept of the rule of law is well known in modern European constitutional traditions and enshrined in a number of international human rights instruments and other standard-setting documents. ${ }^{201}$ As it stated in the Judgment of the ECJ of 23 April 1986 "....[i]t must first be emphasized in this regard that the European Economic Community is a community based on the rule of law, inasmuch as neither its Member States nor its institutions can avoid a review of the question whether the measures adopted by them are in conformity with the basic Constitutional Charter, the Treaty." ${ }^{202}$ Fifteen years later, in 2001 the so-called Laeken (Declaration on the Future of the European Union) emphasised that"...[E]urope as the continent of humane values, the Magna Carta, the Bill of Rights, the French Revolution and the fall of the Berlin Wall ${ }^{203}$; the continent of liberty, solidarity and above all diversity, meaning respect for others' languages, cultures and traditions. The European Union's one boundary is democracy and human rights. The Union is open only to countries which uphold basic valuessuch as free elections, respect for minorities and respect

\footnotetext{
${ }^{201}$ In the preamble of the Universal Declaration of Human Rights (dated 1948) it reads: 'it is essential, if man is not to be compelled to have recourse, as a last resort, to rebellion against tyranny and oppression, that human rights should be protected by the rule of law.'

http://www.un.org/en/universal-declaration-human-rights/[17--11-2017]

${ }^{202}$ Case 294/83, "Les Verts" v European Parliament, [1986] ECR 01339, para 23.

http://eur-lex.europa.eu/legalcontent/EN/TXT/HTML/?uri=CELEX:61983CJ0294\&from=EN[17--11-2017]

${ }^{203}$ After several weeks of civil unrest, the East German government announced on 9 November 1989 that all GDR citizens could visit West Germany and West Berlin.
} 
for the rule of law." 204 In 2009 the Lisbon Treaty emphasized, that the rule of law is one of the founding principles stemming from the common constitutional traditions of all Member States, and is one of the fundamental values upon which the European Union is based. Respect for the rule of law is a prerequisite for the protection of all fundamental values listed in the Treaties, including democracy and fundamental rights, therefor the Treaty strengthened the previous rule of law mechanisms.(Article 7 TEU) ${ }^{205}$ In 2011 the European Commission for Democracy Through Law (Venice Commission of the Council of Europe) published a report refers to the rule of law as "a fundamental and common European standard to guide and constrain the exercise of democratic powers" and as an "inherent part of any democratic society" which "requires everyone to be treated by all decisions-makers with dignity, equality and rationality and in accordance with the law, and to have the opportunity to challenge decisions before independent and impartial courts". ${ }^{206}$ In 2014 the Communication of the European Commission explained that the respect of rule of law is a legally binding constitutional principle of the Union. ${ }^{207}$ In the Annex of the Communication identified the most important but not exhaustive common and generally shared traits of the rule of law. ${ }^{208}$ This document specifies legality ${ }^{209}$, which implies a transparent, accountable, democratic and pluralistic process for enacting laws; legal certainty ${ }^{210}$; prohibition of arbitrariness of the executive powers ${ }^{211}$; independent and impartial courts ${ }^{212}$; effective judicial review including respect for fundamental rights ${ }^{213}$; and equality before the law. ${ }^{214}$ Both the ECJ and the European Court of Human Rights confirmed that these principles are not purely formal and procedural requirements. Safeguarding values, such as the rule of law is a fundamental question in the Union, which requires that not only the EU institution, but the Member States and other relevant stakeholders engage in a constructive dialog.With regard to the link between the rule of law and the human rights, particular attention needed to be given to the development of the human rights in the EU.Having regard to the fact that

${ }^{204}$ Laeken Declaration of 15 December 2001 on the future of the European Union; I. Europe at a crossroads, Europe's new role in a globalised world, European Union document SN 273/01

${ }^{205} \mathrm{http}$ ://ec.europa.eu/justice/effective-justice/rule-of-law/index_en.htm [20-11-2017]

206 Report of the Venice Commission of 4 April 2011 Study No. 512/2009 (CDL-AD (2011)003rev). Adopted by the Venice Commission at its $86^{\text {th }}$ plenary session (Venice, 25-26 March 2011) on the basis of comments by Mr Pieter VAN DIJK (Member, Netherlands), Ms Gret HALLER (Member, Switzerland) Mr Jeffrey JOWELL (Member, United Kingdom) Mr Kaarlo TUORI (Member, Finland)

http://www.venice.coe.int/webforms/documents/ [16-11-2017]

${ }^{207}$ Annexes to the Communication from the Commission to the European Parliament and the Council; A new EU Framework to strengthen the Rule of Law, Strasbourg, 11.3.2014 COM(2014) 158 final http://ec.europa.eu/justice/effective-justice/files/com_2014_158_annexes_en.pdf [17--11-2017] ${ }^{208}$ Ibid.

${ }^{209}$ Case C-496/99 P, Commission v CAS Succhi di Frutta [2004] ECR I-03801, para 63.

210 Joined cases 212 to 217/80 Amministrazione delle finanze dello Stato v Salumi [1981] ECR 2735, para 10.

${ }^{211}$ Joined cases 46/87 and 227/88 Hoechst v Commission [1989] ECR 02859, para 19.

212 Case C-279/09 DEB, [2010] ECR I-13849, para 58.

${ }^{213}$ Case C-583/11 P Inuit Tapiriit Kanatami and Others v Parliament and Council, not yet published, para 91; Case C-550/09 E and F, [2010] ECR I-06213, para 44; Case C-50/00 P Unión de Pequeños Agricultores [2002] ECR I-06677, para 38 and 39.

${ }^{214}$ Case C-550/07 P Akzo Nobel Chemicals and Akcros Chemicals v Commission [2010] ECR I08301 , para 54. 
the human rights of every individual within the Union were established at different times, in different ways, and in different forms, over the last decades, attempts have been made by the Union to elaborate an independent European Union document of human rights. The EU Charter of the Fundamental Rights (hereafter Charter) was drafted by theEuropean Conventionand solemnly proclaimed on 7 December 2000 in Nice by theEuropean Parliament, theCouncil of Ministersand theEuropean Commission. The Charter is bringing together all rights found in the jurisprudence constant of ECJ, the rights and fundamental freedoms enshrined in the European Convention on Human Rights (hereafter ECHR), other rights and principles from the common constitutional tradition of Member States and other international instruments. The main purpose of the EU Charter was to strengthen the protection of fundamental rights in the light of changes in society, social progress and scientific and technological developments by making those rights more visible in a Charter. ${ }^{215}$ The Charter makes a clear distinction between rights and principles, and combines in a single text the civil, political, economic, social and societal rights, which had previously been laid down in a variety on international, European and national sources. Originally, the EU Charter was not legally binding, but in 12 December 2007 it was amended and the Treaty provides that the EU shall 'recognise the rights, freedoms and principles set out in the Charter of Fundamental Rights of the European Union "...[w] hich shall have the same legal value as the Treaties."This way the Charter gained full legal effect after Lisbon Treaty came into the force on December 1, 2009.The EU Charter therefore constitutes primary EU law, integral part of the EU law, setting out the fundamental rights, which every Union citizen can benefit from. However, the EU Charter only applies within the scope of EU law, the provisions of the Charter apply to the institutions and bodies of the EU, with due regard for the principle of subsidiary, and national authorities only when they are implementing EU law. ${ }^{216}$ Article 53 clearly states that the EU Charter cannot restrict or adversely affect the level of protection of fundamental rights already provided by Union law, international law including the ECHR and the Member States' constitutions. The EU Charter is equally applicable to all the Member States of the European Union.

It is important to consider that the EU Charter is supplemented by a protocol with a number of derogations for the United Kingdom, which states that neither the national courts of United Kingdom nor the Court of Justice may declare United Kingdom law incompatible with the Charter. Poland later joined this compromise and concluded the same opt-out. Although a Protocol (No. 30) has been adopted to clarify its application to the United Kingdom and Poland, it does not limit or rule out its impact on the legal orders of these two Member States, as expressly recognised by the

${ }^{215}$ The EU Charter responds to recent calls, such as information technology or genetic engineering by enshrining rights e.g. the protection of personal data or rights in connection with bioethics and transparent administration. The main sources of inspiration for the EU Charter were; the ECHR and the constitutional traditions common to the EU member states, as general principles of Community law, the European Social Charter $(\mathrm{CoE})$ and the Community Charter of the Fundamental Social Rights of Workers.

${ }^{216}$ The material scope of application of the EU Charter is defined expressly in Article 51, which states that its provisions are addressed only to the EU institutions and bodies and, when they act to implement EU law, to the Member States. The EU Charter does not bind states unless they are acting to implement EU law and it does not extend the powers or competences of the Union, it does not increase the powers of the Union to the detriment of those by the Member States. Articles 52 and 53 of the EU Charter stipulate that fundamental rights must be interpreted in harmony with the constitutional traditions common to the Member States, as well as with the ECHR, and with full account taken of national laws and practices. 
Court of Justice inN.S., Case C-411/10. ${ }^{217}$ The ECJ assumed that EU law does not permit a conclusive presumption that Member States observe the fundamental rights conferred on asylum seekers. ${ }^{218}$ The Court also stated that its answers did not require being qualified in any respect to take account of Protocol (No. 30) on the application of the EU Charter to Poland and the United Kingdom.

The human rights also guide the Union's action both inside and outside its borders. The European Union attaches a great importance to promoting and protecting the universality and indivisibility of all human rights in partnership with countries from all regions, in close cooperation with international and regional organisations and with civil society. In particular, the requirement of the respect for human rights was kept in mind in foreign relations, rather of a general nature based on regional or bilateral treaties, agreements or conventions or strategic partnerships dealing systematically with the issue of human rights. ${ }^{219}$ Following the adoption of the Agenda for Change and the Strategic Framework on Human Rights and Democracy in 2012, the EU became committed to moving towards a Rights-Based Approach (RBA) for development cooperation. ${ }^{220}$ Accession partnerships, including EU pre-accession financial aid, are conditional upon compliance with the requirement of respect for democratic principles. If the rule of law, respect for human rights or the protection of minorities are violated, if the country concerned fails to make continuous progress towards the fulfilment of any one of the above mentioned conditions, the partnership will have to be suspended.

Special attention should be given to the Candidate Countries of the EU namely Turkey, the former Yugoslav Republic of Macedonia, Montenegro, Serbia and Albania, the country of the Stabilisation and Association Process (SAP) and potential candidate Bosnia and Herzegovina. The European perspective of the Western Balkans, confirmed in the Thessaloniki Declaration of June $2003^{221}$, is

217 Judgment in Joined Cases C-411/10, N.S. v. Secretary of State for the Home Department and C493/10 M.E. and Others v. Refugee Applications Commissioner, Minister for Justice, Equality and Law Reform, 2011. www.refworld.org/docid/4ef1ed702.html [24-09-2017]

${ }^{218}$ Without question, in recent decadesthe EJC elaborated a catalogue of human rights drawn from the general principles of Community law and from the common constitutional traditions of the Member States.

${ }^{219}$ These include in particular: relations with candidate countries, the Cotonou Agreement with the ACP States, relations between the EU and Latin America, the Barcelona process (Mediterranean countries) and the neighbourhood policy (countries of the Caucasus in particular), political dialogue with Asian countries in the context of ASEAN and ASEM, relations with the Western Balkans countries and bilateral relations in the framework of association and cooperation agreements.

220 "The Council notes that the implementation of a rights-based approach to development cooperation should be based on the universality and indivisibility of human rights and the principles of inclusion and participation in decision-making processes; non-discrimination, equality and equity; transparency and accountability. The application of these principles should be central to EU development cooperation, thereby also ensuring the empowerment of the poorest and most vulnerable, in particular of women and girls, which in turn contributes to poverty reduction efforts."Council conclusions on a rights-based approach to development cooperation, encompassing all human rights Foreign Affairs (Development) Council meeting Brussels, 19 May 2014 http://www.consilium.europa.eu/uedocs/cms_data/docs/pressdata/en/foraff/142682.pdf [11-122017]

${ }^{221}$ The Thessaloniki agenda for the Western Balkans: Moving towards European Integration, C/03/163,Thessaloniki, 21 June 2003, 10229/03 (Press 163) http://europa.eu/rapid/press-release PRES-03-163 en.htm [16-11-2017] 
also open to Kosovo. ${ }^{222}$ These countries must satisfy EU eligibility criteria; respect and commit to the values set out in Article 2 TEU, as respect for human dignity, freedom, democracy, equality and the rule of law respect for human rights, including the rights of persons belonging to minorities; and respect for a pluralistic society and for non-discrimination, tolerance, justice, solidarity and equality between women and men. The applicant countries are required to respect the EU's values and rights, in line with the so-called Copenhagen Criteria set out in December 1993 by the European Council in Copenhagen. ${ }^{223}$

The Copenhagen Criteria requires a candidate country to have stable institutions that guarantee democracy, the rule of law, human rights and respect for and protection of minorities. (So-called political criteria). The main point is that only a European country, which respects these principles may apply to become a member of the Union. In other words, complying with all the EU's standards and rules including the Copenhagen Criteria is an absolute pre-condition of the applicant to fulfil. In the case of the countries of the Western Balkans additional conditions for membership, were set out in the so-called 'Stabilisation and Association Process', mostly relating to regional cooperation and good neighbourly relations. During the accession process, the Commission regularly monitors the candidate's progress in applying EU legislation and meeting its other commitments, including the afore-mentioned political criteria and any benchmark requirements.

It can be stated that the EU seeks to validate its values in its external relations and, in the case of accession countries; the Union is essentially able to force them to be implemented. The simple reason is that these values including the protection of human rights are prerequisites for accession, if a country does not care about taking it seriously, will not be admitted to the Union.

Nevertheless, the EU's credibility in its external relations depends on its own internal arena, this is why the EU try to establish increasing consistency between its internal and external policies in relation to human rights.

\section{Towards a new mechanism of EU to protect its values}

For the first time, in 1995 the so-called Reflexion Group led by Carlos Westendorp has put forward a concrete proposalon a mechanism that is able to enforce fundamental values within the Union. ${ }^{224}$ The Report highlighted that promoting European values Europe's internal security rests on its democratic values, and these common valuesmust clearly proclaim the Treaty. The Report has also been suggesteda provision allowing for the possibility of sanctions or even suspending Union

\footnotetext{
${ }^{222}$ Kosovo is at present under the administration of UNMIK, pursuant to UNSC Resolution 1244 (1999).

Communication from the Commission - A European Future for Kosovo / COM/2005/0156 final, Brussels, 20.4.2005, https://peacemaker.un.org/kosovo-resolution1244and http://eurlex.europa.eu/legal-content/EN

[16-1-2017]

${ }^{223}$ See: Joining the EU - the accession process http://eur-lex.europa.eu/legal-content/EN/TXT/HTML[16-11-2017]

${ }^{224}$ Reflection Group's Report, Messina 2nd June 1995, Brussels 5th December 1995.

"[T]he Group believes that there are European common values that the Union should protect and promote. They are the basis of our democracies, of our security and are also present in the feeling of belonging in the citizens. Essential elements are to be found in respect for fundamental rights, nondiscrimination, and clarification of the rights and obligations of both citizens of the Union and thirdcountry nationals in the Union."

http://aei.pitt.edu/49155/1/B0015.pdf [4-12-2017]Art. 30.of the Report
} 
membership in the case of any state seriously violating human rights and democracy and a procedure for its enforcement. Bearing in mind the findings and suggestions of the Westendorp report, the IGC preparing the Amsterdam Treaty was amended the Treaty by bringing a new mechanism of the protection of fundamental rights within the jurisdiction of the ECJ. In 2003 the Nice Treaty added a preventive arm to this mechanism and in 2009 the Lisbon Treaty (Treaty of the European Union-TEU) reinforced the procedure in case a "serious and persistent breach" may occur by a Member State of the values referred to in Article 2 (dignity, freedom, liberty, democracy, and equality, rule of law, human rights and rights of minorities). This legal mechanism, so-called 'nuclear option' provides for special mechanisms with far-reaching sanctions in case a Member State does not respect the fundamental values referred to in Article 2 TEU, including the rule of law. The often cited Article 7 TEU aims at ensuring that all EU countries respect the common values of the EU, including the rule of law. This Article was established as a way to hold EU Member States accountable for violation of the European values and fundamental rights. Under paragraph 1 of Article 7 TEU, four-fifths of the EU's members can determine in the Council of Ministers that there is a "clear risk of a serious breach by a Member State of the values referred to in Article 2," based on a reasoned proposal by one-third of the member states, the parliament, or the commission. Under paragraph 2, the European Council (the heads of state and government), after hearing from the offending state, can decide by unanimity among all other members that there is a "serious and persistent breach" of values. Paragraph 3 then allows the Council of Ministers to suspend certain of that country's rights, including its government's voting rights. In doing so, the Council shall take into account the possible consequences of such a suspension on the rights and obligations of natural and legal persons.The obligations of the Member State in question under the Treaties shall in any case continue to be binding on that State. ${ }^{225}$ To be worth considering that the threshold for activating Article 7(2) was set very high to make sure that it could apply only to extreme cases.In April 2013, the General Affairs Council held a comprehensive discussion on the topic. ${ }^{226}$ In June 2013, the Justice and Home Affairs Council underlined that "respecting the rule of law is a prerequisite for the protection of fundamental rights" and called on the Commission "to take forward the debate in line with the Treaties on the possible need for and shape of a collaborative and systematic method to tackle these issues". The resolution adopted by the European Parliament on 3 July 2013 considered that at this stage of European integration the capacity to address threats to the rule of law within the EU needs to be strengthened. In September 2013, Viviane REDINGhas described as a new 'preArticle 7 procedure' to strengthen the rule of law suggesting an early warning tool whose primary aim is to enable the EU Commission to enter into a structured dialogue with the Member State concerned to prevent the escalation of systemic threats to the rule of law. ${ }^{227}$ The potential

${ }^{225}$ Consolidated of the Treaty on European Union (TEU) and the Treaty on the Functioning of the European Union (TFEU) as amended by the Treaty of Lisbon (2007) [13-09-2017].

${ }^{226}$ Communication from the Commission to the European Parliament and the Council, A new EU Framework to strengthen the Rule of Law, $\operatorname{COM}(2014) 158$ final p.3. http://ec.europa.eu/justice/effective-justice/files/com_2014_158_en.pdf [04-12-2017]

${ }^{227}$ In a well-noted speech on 4 September 2013, Viviane Reding (Speech/13/677), former EU Commissioner for Justice, drew an interesting parallel between Europe's economic and financial crisis and what she viewed as an increasing number of 'rule of law crises' revealing problems of a systemic nature. She highlighted that only systemic threats or violations of the rule of law may trigger the activation of this new mechanism, not minor or individual breaches;(ii) Unlike the current monitoring tool specifically developed for Romania and Bulgaria, this new procedure would apply equally to all Member States, regardless of the date of entry into the EU, size, etc. (iii) While the Commission will continue to remain the guardian of EU values, third party and/or external 
modification of the Article 7 procedure has been a running theme in the EU, but this would mean the amendment of the Lisbon Treaty, and it would be possible only with the unanimous will of the EU Member States.Interpreted in this way the provision at issue contains nothing capable of prejudicing the fundamental human rights enshrined in the general principles of Community law and protected by the Court. ${ }^{228}$

On 19 March 2014 in its Communication 'A new EU Framework to strengthen the Rule of Law' the European Commission adopted a new tool to address systemic threats to the rule of law in any of the EU's Member States.229The new EU Framework is aiming to prevent, through a dialogue with the Member State concerned, that an emerging systemic threat to the rule of law escalates further into a situation where the Commission would need to make use of its power of issuing a proposal to trigger the mechanisms of Article 7 TEU. In its reasoning, the Communication just described "... $\mathrm{t}$ ] hat different constitutions and judicial systems of the EU Member States are, in principle, well designed and equipped to protect citizens against any threat to the rule of law. However, recent events in some Member States have demonstrated that a lack of respect for the rule of law and, as a consequence, also for the fundamental values which the rule of law aims to protect, can become a matter of serious concern. During these events, there has been a clear request from the public at large for the EU, and notably for the Commission, to take action."The framework seeks to resolve future threats to the rule of law in Member States before the conditions for activating the mechanisms foreseen in Article 7 TEU would be met. It is therefore meant to fill a gap.230 It is not an alternative to but rather precedes and complements Article 7 TEU mechanisms. The Commission stated, if such a threat cannot be effectively addressed by the safeguards at national level, or by the existing instruments at EU level, in particular infringement procedures, the Framework could be applied. The new Framework establishes a three-stage process: a Commission assessment, a Commission recommendation and monitoring of the Member State's follow-up to the Commission's recommendation. This is an adversarial procedure, which means that at all stages, a dialogue should be maintained between the Commission and the Member State concerned. As the former President of the European Commission, José Manuel Barosso explained it, this new mechanism will be activated only in situations where there is a serious and systemic risk to the rule of law, and triggered by predefined benchmarks.231If however no solution is found within the new Framework, Article 7 TEU will always remain the last resort to resolve a crisis and ensure the Member State complies with EU values.

In June 2015 the European Parliament suggested in its resolution to create an annual monitoring of compliance with democracy, the rule of law and the situation of fundamental rights in all Member States through a Scoreboard, to be established on the basis of common and objective indicators. The suggestion of the EU Justice Scoreboard - which is an information tool which aims to assist the EU

expertise may be sought when necessary. The EU Fundamental Rights Agency, the Council of Europe (in particular, the Venice Commission) and judicial networks such as the Network of the Presidents of the Supreme Judicial Courts of the EU could therefore be asked to provide expert knowledge, notably during the assessment phase.See: V. Reding, 'A new Rule of Law initiative', Press Conference, European Parliament, Strasbourg, 11 March 2014.

${ }^{228}$ Judgment of 12 November 1969 in Case 29/69 Erich Stauder v. City of Ulm, [1969] ECR 419 at p. 419.

${ }^{229}$ Communication from the Commission to the European Parliament and the Council, A new EU Framework to strengthen the Rule of Law, COM(2014) 158 final

${ }^{230}$ Ibid. p.

${ }^{231} \mathrm{http} / / /$ europa.eu/rapid/press-release_SPEECH-13-684_en.htm 
and the Member States in achieving more effective justice by providing objective, reliable and comparable data on the functioning of justice systems in all Member States -could fit into the timetable of the European Semester ${ }^{232}$ and could be linked to the Cycle of Economic Governance ${ }^{233}$ as well.

First time the new framework for addressing systemic threats to the rule of law was used concerning Poland. First Vice-President of the European Commission Frans TimMERMANS visited Poland two times; on 5 April and on 24 May 2016 for exchanges with his Polish counterparts on how to resolve the situation. Extensive exchanges took place between the Commission and the Polish Government in meetings at various levels. However, despite these exchanges it was not possible to find a solution to the issues identified by the Commission. On 1 June 2016 the Commission adopted an Opinion setting out the concerns of the Commission and served to focus the ongoing dialogue with the Polish authorities on finding a solution. In spite of every effort of the Commission and the views of the Venice Commission, on 22 July, the Polish Parliament adopted a new law on the Constitutional Tribunal, and a number of important concerns already raised remain. ${ }^{234}$ In July 2016 the Commission formulated that "Recent events in Poland, in particular the political and legal dispute concerning the composition of the Constitutional Tribunal, the non-publication of judgments rendered by the Constitutional Tribunal, as well as the review of the law on the Constitutional Tribunal and its impact on the effectiveness of constitutional review of new legislation have given rise to concerns regarding the respect of the rule of law."As a second step in the process under the Rule of Law Framework, the Commission issued a Recommendation on 27 July 2016 setting out the reasons why the Commission considers that there is still a systemic threat to the rule of law in Poland and recommending how this situation can be addressed.

\section{The long way to triggering Article 7 (1)}

If we look at the consistency with fundamental values of the EU Member States, it might be concluded that one of the Member States does not fully meet all requirements, no Member State is perfect.At the same time, we could also state that there are some Member States that behave visibly and deliberately contrary to the rules and values set out in the Treaties. Among them, the Hungarian Fidesz and the Polish Law and Justice (PiS) leaded governments have the intention to transformof

${ }^{232}$ Besides reforming supervision of EU financial markets, a 'European semester' is a cycle of economic policy coordination to ensure from 2011 that national economic and fiscal policies are assessed by the European institutions first before they are adopted by Member States. The European semester is based on a coordination process lasting several months with fixed calendar deadlines.

${ }^{233}$ The EU responded by taking a wide range of measures to strengthen its governance and to facilitate a return to sustainable economic growth, job creation, financial stability and sound public finances. Central pillars of these efforts are: the legislative packages to strengthen the Stability and Growth Pact known as the "Six Pack" and "Two Pack", and the Treaty on Stability, Coordination and Governance in the Economic and Monetary Union.

${ }^{\mathbf{2 3 4}}$ COMMISSION RECOMMENDATION REGARDING THE RULE OF LAW IN POLAND:

QUESTIONS \& ANSWERS, BRUSSELS, 27 JULY 2016, $\underline{\text { HTP://EUROPA.EU/RAPID/PRESS- }}$

RELEASE_MEMO-16-2644_EN.HTM [30.10.2017.] 
many independent state institutions according to their own ideas, and undermined the appropriate implementation of EU law as well. In his speech of First Vice-President Frans Timmermans to the European Parliament stated that "The clearest way to show what the rule of law means to us in everyday life is to recall what has happened when there is no rule of law. ${ }^{235} \mathrm{He}$ also underlined that ,...[I] will personally see to it that the Commission acts in a non-ideological manner, and assesses each case fairly and objectively, based on the facts of the case, and on the law. The Commission will act impartially and treats all Member States equally. Our purpose is not to sanction individual Member States per se, but rather to address issues through targeted intervention to restore the correct application of EU law."He highlighted later in another speech that"... [t]he Commission must also remain an impartial, objective and independent arbiter, and base itself on the law and the facts on the ground." The European Parliament in its resolution of 10 June 2015 expressed its concern on the situation in Hungary ${ }^{236}$ and called on the EU Commission to present a proposal for the establishment of an EU mechanism on democracy, the rule of law and fundamental rights, as a tool for compliance with and enforcement of the Charter and Treaties as signed by all Member States. ${ }^{237}$

As Timmermans reported in August 2015"...[I]n all too many places across Europe today, we see alarming tendencies emerging. And as happens frequently in times of crisis, it is members of minorities - be they racial, religious, ethnic or other - who are the first to be singled out as scapegoats. It starts with imperceptible signs, then grows into illiberal temptations, and even into talk in certain quarters, of 'illiberal democracy'." He was asked in his speech"...[S]o do we have the enough tools, and the right tools, at our disposal in order to ensure the rule of law across Europe?" According to him, the right answer was, no. He was referring to the Hungarian case, when criticisms have been made against the Commission that the Commission for not having activated the Rule of Law Framework yet. The Commissioner has refused to comment on what he says that a new framework should be elaborated, or those that demanded it the recent framework should be more automatic, maybe even with parameters that trigger the application of the framework similar to mechanisms we find in the field of economic policy." 238

In December 2015 the European Parliament reiterated its position expressed in its resolution of 10 June 2015 on the situation in Hungary. ${ }^{239}$ The Parliament repeated its main concerns about the

\section{COMMISSION STATEMENT: EU FRAMEWORK FOR DEMOCRACY, RULE OF LAW}

AND FUNDAMENTAL RIGHTS, STRASBOURG, 12 FEBRUARY 2015

http://europa.eu/rapid/press-release_SPEECH-15-4402_en.htm [26-11-2017]

236 Resolution (2015/2700(RSP)

http://www.europarl.europa.eu/sides/getDoc.do [27-11-2017]

237 Ibid.

238 THE EUROPEAN UNION AND THE RULE OF LAW - KEYNOTE SPEECH AT

CONFERENCE ON THE RULE OF LAW, TILBURG UNIVERSITY, 31 AUGUST 2015

https://ec.europa.eu/commission/commissioners/2014-2019/timmermans/announcements/europeanunion-and-rule-law [21-11-2017]

239 Situation in Hungary: follow-up to the European Parliament Resolution of 10 June 2015

European Parliament resolution of 16 December 2015 on the situation in Hungary (2015/2935(RSP)) http://www.europarl.europa.eu/sides/getDoc.do [22-11-2017] 
treatment of the refugees, migrants and asylum-seekers, ${ }^{240}$ stating that all Member States must comply fully with EU law in their legislative and administrative practice, and that all legislation must reflect and be in accordance with basic European values, namely democracy, the rule of law and fundamental rights. The Parliament believed that Hungary was a test for the EU to prove its capacity and political willingness to react to threats and breaches of its own founding values by a Member State. The Parliament also drew attention to that the Union had to ensure continuing respect for the political Copenhagen criteria once a Member State has acceded to the Union. In the end of its resolution, the Parliament... [R] eiterates the call on the Commission to activate the first stage of the EU framework to strengthen the rule of law, and therefore to initiate immediately an indepth monitoring process concerning the situation of democracy, the rule of law and fundamental rights in Hungary, including the combined impact of a number of measures, and evaluating the emergence of a systemic threat in that Member State which could develop into a clear risk of a serious breach within the meaning of Article 7 TEU"241

In January 2016 the Commission expressed his concern on the developments in Poland, in particular the political and legal dispute concerning the composition of the Constitutional Tribunal, have given rise to concerns regarding the respect of the rule of law. ${ }^{242}$ The Commission concluded in 2016 that the PiS government's attempts to gain control of the Polish Constitutional Tribunal were a systemic threat to the rule of law. As'guardian of the treaties', the Commission launched a dialogue under the

240 2. Voices serious concerns regarding the series of swift legislative measures taken in recent months that have rendered access to international protection extremely difficult and have unjustifiably criminalised refugees, migrants and asylum seekers; stresses its concerns regarding respect for the principle of non-refoulement, the increasing recourse to the detention, including of minors, and the use of xenophobic rhetoric linking migrants to social problems or security risks, in particular through government-led communication campaigns and national consultation, thereby making integration problematic; urges the Hungarian Government to return to normal procedures and repeal emergency measures; Ibid.

241 Ibid. Point 8

${ }^{242}$ On 19 November, the new legislature, through an accelerated procedure, amended the Law on the Constitutional Tribunal, introducing the possibility to annul the judicial nominations made by the previous legislature and to nominate five new judges. The amendment also shortened the terms of office of the President and Vice-President of the Tribunal from nine to three years, with the current terms coming to an automatic end within three months of the amendment's adoption. On 25 November the new legislature annulled the five nominations by the previous legislature and on 2 December nominated five new judges.

The Constitutional Tribunal was seized concerning the decisions of both the previous legislature and the incoming legislature. The Tribunal delivered two judgements, on 3 and 9 December 2015.

On 3 December, the Court ruled that the previous legislature was entitled to nominate three judges for seats vacated during its mandate, but was not entitled to make the two nominations for seats vacated during the term of the new legislature.

On 9 December, the Court ruled that the new legislature was not entitled to annul the nominations for the three appointments under the previous legislature, but that it was entitled to appoint the two judges whose mandate began under the incoming legislature. The Constitutional Tribunal also declared invalid the shortening of the terms of office of the current President and Vice-President of the Tribunal.

http://europa.eu/rapid/press-release_MEMO-16-62_en.htm[16-10-2017] 
Rule of Law Framework, introduced a new mechanism in 2014 as a precursor to Article 7. Despite all these, the efforts of the Commission appeared to be powerless, and the endless dialogues have not proved effective. After that dialogue yielded no results, the European Commission First Vice-President Frans Timmermans concluded that the measures proposed by the Polish government "...[w] ould abolish any remaining judicial independence. . . [because] judges will serve at the pleasure of the political leaders and be dependent upon them from their appointment to their pension." The European Parliament had already expressed concern about the "danger to democracy, human rights and the rule of law" in Poland. ${ }^{\mathbf{2 4 3}}$ At the same time as the Polish events, the EU Commission took the Hungarian government to ECJ over laws that would restrict the operations of universities in Hungary (so-called lex CEU) and odds with Budapest over other rights issues, including a crackdown on foreign-backed civil society groups that receive foreign funding.The Venice Commission stressed in its report that despite its legitimate aims, the law may not be used to stigmatize NGOs or restrict their ability to carry out their activities. The law causes disproportionate and unnecessary interference with freedom of expression and association, the right to privacy and non-discrimination. ${ }^{244}$ The EU Commission has already launched infringement procedures against Hungary for its harsh treatment of asylum seekers and its refusal to take in refugees relocated from Italy and Greece under a plan adopted by the Council of Ministers, in which Hungary and Slovakia was outvoted.The EU launched legal action 13 June 2017 against Hungary, Poland and the Czech Republic for refusing to take in their share of refugees under a controversial solidarity plan.Despite the efforts of the EU Commission neither Hungarian, nor Polish government showed any sign of changing course, PiS because of its ideological agenda and Fidesz because of the forthcoming parliamentary election in $2018 .{ }^{245}$ The big danger is, the undesirable political influence over the basic constitutional institutions, would have a negative sideeffect disrupting judicial and police cooperation among the Member States, and the objectionable pattern of the Hungarian and Polish governments would also have imperil the Schengen area of passport-free travel. The implementation of EU law would be also in the danger, if some Member States could continue going against the basic values stipulated in the Treaties, without consequences. These undesirable phenomena threaten the EU as a whole, the importance of the EU as foreign policy actor.

On 26 April 2017 the European Parliament held again a debate on Hungary. In his opening remarks First Vice-President Frans Timmermans said that the Commission shares the worries and concerns

243 European Parliament resolution of 14 September 2016 on the recent developments in Poland and their impact on fundamental rights as laid down in the Charter of Fundamental Rights of the European Union (2016/2774(RSP)

${ }^{244}$ Strasbourg, 20June2017 Opinion889/ 2017CDL-AD(2017)015

European Commission for Democracy Through Law (Venice Commission) Hungary opinion on the draft law on the transparency of organisations receiving support from abroad

Adopted by the Venice Commissionat its 111thPlenary Session(Venice, 16-17 June 2017)on the basis of comments byMs Veronika BÍLKOVÁ (Member, Czech Republic)Mr Richard CLAYTON (Member, United Kingdom)Ms HerdísKJERULF THORGEIRSDOTTIR (Vice-President,Member, Iceland)

http://www.venice.coe.int/webforms/documents/default.aspx?pdffile=CDL-AD(2017)015-e[12-122017]

245 Stefan LEHNE:Defending EU Values in Poland and Hungary, Carnegie Europe, September 04, 2017

http://carnegieeurope.eu/2017/09/04/defending-eu-values-in-poland-and-hungary-pub [16-10-2017] 
on the recent developments in Hungary, and about the compatibility of certain actions of the Hungarian authorities with EU law and with the shared European values including the rule of law. In the debate, Manfred Weber, the president of the European People's Party (EPP)-group to which also the Fidesz belongs, made a harsh criticism on the Hungarian legislation. ${ }^{246}$ The illiberal Hungarian model also was criticizing by the MEPs and an MEP expressed the opinion that Hungary would like continue taking the European Union's money, but not the European values. ${ }^{247}$

On 7 December 2017, the Committee on Civil Liberties, Justice and Home Affairs of the European Parliament was organising a public hearing on "The situation in Hungary". The hearing was initiated by Green MEP Judith Sargentini, who will submit an updated report on Hungary within the coming weeks. ${ }^{248}$ The hearing was based on the European Parliament resolution of 17 May 2017 on the situation in Hungary ${ }^{249}$ and MEPs appreciated the positive gesture that Hungarian government had attended the hearing at all. Following steps may take place in the spring of next year.

${ }^{246}$ Manfred Weber, im Namen der PPE-Fraktion. - Sehr geehrter Herr Präsident, sehr geehrter Herr Vizepräsident, sehr geehrter Herr Premierminister! Es geht heute nicht um Soros. Ich verstehe eines nicht. Seit 25 Jahren gibt die Zentraleuropäische Universität in Budapest zwei Diplome aus: ein amerikanisches und ein ungarisches. Seit 25 Jahren ist das gute Praxis, sie hat sich ein Renommee erarbeitet. Ungarische Studenten haben davon einen Vorteil, weil sie in ihrer Stadt in Budapest - zwei Abschlüsse bekommen. Ich, und ich darf das für meine gesamte Fraktion sagen, lieber Herr Premierminister, wir verstehen einfach nicht, warum dieser Vorteil jetzt dieser Universität weggenommen wird.

http://www.europarl.europa.eu/sides/getDoc.do?pubRef=-//EP//TEXT[12-12-2017]

${ }^{247}$ Marie-Christine Vergiat (GUE/NGL). - Monsieur le Président, la «démocratie illibérale», nouveau modèle hongrois, c'est la mise au pas progressive mais systématique des contre-pouvoirs: médias, justice, éducation, ONG. La consultation «Stoppons Bruxelles» est une caricature et le projet de loi sur les ONG, calqué sur la loi russe, n'est pas un texte de transparence, mais de suspicion.

S'agissant de la question migratoire, on peut se demander si le droit d'asile existe encore en Hongrie. La convention de Genève n'est plus respectée: détention systématique, y compris des mineurs; construction d'un mur le long de la Serbie - désormais électrifié; droit de tirer à vue pour les «chasseurs de frontière»; les amalgames, les mensonges sont rois, les boucs émissaires multiples - on vient encore de l'entendre. L'absence d'action de la Commission depuis décembre 2015, tout comme le silence de M. Avramopoulos à son retour de Hongrie, nous a inquiétés. Je me félicite donc, Monsieur Timmermans, que la Commission ait enfin décidé d'ouvrir une procédure d'infraction et qu'une résolution soit soumise au vote de la prochaine plénière. Monsieur Orbán, on ne joue pas avec les libertés, surtout dans un pays dont l'histoire est celle de la Hongrie. Ibid.

248 As part of the preparatory work for the report to be drafted by Judith Sargentini (Greens/EFA, $\underline{\mathrm{NL}}$, MEPs held a hearing in which Hungary Foreign Affairs and Trade Minister Péter Szijjàrtó presented the government's views. Hungarian Helsinki Committee Co-Chair Marta Pardavi, University of Pécs, and Mertek Media Monitor representative Gábor Polyák, as well as Centre for Fundamental Rights Director Miklós Szánthó also took part.

http://www.europarl.europa.eu/news/en/press-room/20171205IPR89530/rule-of-law-anddemocracy-in-hungary

[15-12-2017]

$249 \underline{(2017 / 2656(\mathrm{RSP})}$ 
On 20 December 2017 the EU commission announced its decision 'Rule of Law: European Commission acts to defend judicial independence in Poland':" [D] espite repeated efforts, for almost two years, to engage the Polish authorities in a constructive dialogue in the context of the Rule of Law Framework, the Commission has today concluded that there is a clear risk of a serious breach of the rule of law in Poland. The Commission is therefore proposing to the Council to adopt a decision under Article 7(1) of the Treaty on European Union." In its Reasoned Proposal for a Council Decision, the Commission stated that over a period of two years, the Polish authorities have adopted more than 13 laws affecting the entire structure of the justice system in Poland, impacting the Constitutional Tribunal, Supreme Court, ordinary courts, National Council for the Judiciary, prosecution service and National School of Judiciary. The common pattern is that the executive and legislative branches have been systematically enabled to politically interfere in the composition, powers, administration and functioning of the judicial branch. ${ }^{250}$ The Commission's recommendation clearly sets out a set of actions that need to be taken by the Polish authorities to address its concerns. The Polish authorities are invited to amend the Supreme Court law, not apply a lowered retirement age to current judges, remove the discretionary power of the President to prolong the mandate of Supreme Court judges, and remove the extraordinary appeal procedure, which includes a power to reopen final judgments taken years earlier. Moreover, mend the law on the National Council for the Judiciary, to not terminate the mandate of judges-members, and ensure that the new appointment regime continues to guarantee the election of judges-members by their peers. The Commission suggested to amend or withdraw the law on Ordinary Courts Organisation, in particular to remove the new retirement regime for judges including the discretionary powers of the Minister of Justice to prolong the mandate of judges and to appoint and dismiss presidents of courts. The Commission requested the Polish Government to restore the independence and legitimacy of the Constitutional Tribunal, by ensuring that its judges, President and Vice-President are lawfully elected and by ensuring that all its judgements are published and fully implemented. Last but not least, refrain from actions and public statements which could further undermine the legitimacy of the judiciary ${ }^{251}$ The next steps will certainly be followed by large public interest. In line with the Commission's Recommendation the Polish authorities are invited to address the problems within three months, and to inform the Commission of the steps taken to that effect. The Commission can do nothing other than stand ready to pursue a constructive dialogue with the Polish Government. Should the Polish authorities implement the recommended actions, the Commission is ready, in close consultation with the European Parliament and the Council, to reconsider its Reasoned Proposal. As it is an adversarial procedure, under Article 7(1) TEU, the Council must hear Poland's position and obtain the consent of the European Parliament, which has consistently supported the Commission's concerns, including in the three Resolutions of 13 April 2016, 14 September 2016 and 15 November $2017 .{ }^{252}$ Before adopting a Decision by a four-fifths majority (22 of 27 Members

250 http://europa.eu/rapid/press-release_IP-17-5367_en.htm [24-12-2017]

251 "A wide range of other actors at European and international levels have expressed their deep concern about the reform of the Polish justice system: representatives of the judiciary across Europe, including the Network of Presidents of the Supreme Judicial Courts of the European Union and the European Network of Councils for the Judiciary, the Venice Commission, the Commissioner for Human Rights of the Council of Europe, the United Nations Human Rights Committee as well as numerous civil society organisations such as Amnesty International and the Human Rights and Democracy Network." Ibid.

252 On the basis of Article 354 TFEU, the European Parliament shall act by a two-thirds majority of votes cast, representing the majority of its component Members. 
of the Council entitled to vote on the basis of Article 354 TFEU), determining that there is a clear risk of a serious breach of the rule of law. The Council may also address recommendations to Poland, acting in accordance with the same voting procedure.

Hungary immediately has announced to block any Article 7 sanctions that the EU might propose against Poland.It is important to stress, however, if Article 7(1) was successfully launched, is a powerful political message even if mutual protection between Hungarian and Polish governments makes it impossible to gain unanimity in the European Council to activate any sanctions. Only one case would be a theoretical possibility to use any sanction if against both countries were to start the Article 7process.

Apparently the current EU rules are completely inadequate to effectively force the protection its fundamental values. It is unlikely that the Treaty will be changedby the Member States so there remains the wrangling, the political bargaining. It cannot be emphasized too strongly thatthe credibility of the European Union is at stake, so further efforts would be necessary to modify and refine the existing mechanism.

\section{Conclusions}

The refinement of the rule of law mechanism of the EU has already begun in 2014, but this is far from enough for the EU to function effectively in this area. The EU has been seeking a constructive dialogue with the countries concerned, but given that only Hungary has shown itself to be a partner in this dialogue, and the Polish governments has until January 2018 refused to back down in the face of criticism from the EU, the applicability of this dialogue is strongly questionable. The recent visit on 9January 2018 of the new Polish Prime Minister Mateusz Morawiecki in Brussels is an encouraging sign, howeverthis case cannot be described as a breakthrough. To be worth considering that as his first ever bilateral foreign visit Mateusz Morawiecki visited Hungary.253It also may be noted, that Mateusz Morawiecki stated when he was announcing the new appointments of his government that "...[T] he new government should help us build a sovereign Poland within a strong Europe, a Europe of homelands."254In the discussions in Brussels, Mateusz Morawiecki made efforts to patch up relations with the European Union, but it also made it clear that he would not unwind the country's most-contested judicial reforms, together with Poland's refusal to host

\footnotetext{
$\mathbf{2 5 3}_{\text {MATEUSZ MORAWIECKI MET WITH HUNGARY'S PRIME MINISTER VIKTOR }}$ ORBAN AND PRESIDENT JÁNOS ÁDER IN BUDAPEST ON 3 JANUARY 2018 IN A SHOW OF SOLIDARITY AGAINST EU CRITICISM OF THEIR COUNTRIES' JOINT

BACKTRACKING ON DEMOCRATIC VALUES AND THE RULE OF LAW. ORBAN

CALLED THE PROCEDURE AGAINST POLAND "DEEPLY UNFAIR AND UNJUST".

Poland Reshuffles Government, Hoping to Ease Tensions with E.U. https://www.nytimes.com/2018/01/09/world/europe/poland-cabinet-reshuffle.html [10-01-2018]

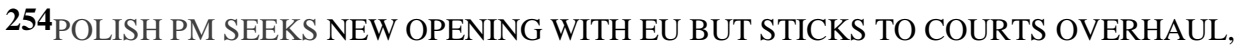
BY PAWEL SOBCZAK, GABRIELA BACZYNSKA, HTTPS://AF.REUTERS.COM/ARTICLE/WORLDNEWS/IDAFKBN1EY180[10-01-2018]
} 
refugees.This issue is closely related to the fact that Poland and Hungary, along with the Czech Republic, have refused to take in asylum seekers despite an EU decision in 2015 to do so, and as a result the EU Commission has referred the countries to the ECJ in December 2017.255

It should further be mentioned that, facing unprecedented EU legal action over accusations of backsliding on democracy by politicizing Polish courts, the ruling Law and Justice (PiS) party may seek to ease tensions in other areas like environmental policy (spearheaded large-scale logging in an ancient UNESCO-protected forest Białowieża)256or defence. (The Polish defence Minister Antoni Macierewicz, facing criticism over delays in modernizing the army as well as conflicts with top generals).257After nearly three hours of talks with European Commission President Jean-Claude Juncker, they issued a joint statement that their dinner was "friendly" and included a "detailed discussion" on the rule of law issues in Poland. Mateusz Morawiecki and Jean-Claude Juncker would meet again "with the view to making progress by the end of February 2018."258 EU Member States (27) will on 27 February 2018 look into whether Poland is backsliding on democracy, though the most powerful sanction of suspending Poland's EU voting rights in the Council is unlikely to materialize, as Hungary several times has declared it would block any such punishment. It is likely that the other member States ask again the Polish government to make changes, issuing recommendations echoing those by EU that the PiS has so far ignored, and giving it some time to react. The dialogue would be also difficult between EU and the two Member States concerned because they are not using the same language. The best example of this is that the wording migrant or illegal migrant are consciously and consistently used instead of refugees. Public opinion in both countries is faced with the unilateral and martial communication of the government, which cannot be sufficiently counterbalanced by the EU. Although the European Parliament and the European Commission also have challenged the tone and content of misleading so-called national

255"Despite the confirmation by the Court of Justice of the EU of the validity of the relocation scheme in its ruling from the 6 September, the Czech Republic, Hungary and Poland remain in breach of their legal obligations. The replies received were again found not satisfactory and three countries have given no indication that they will contribute to the implementation of the relocation decision. This is why, the Commission has decided to move to the next stage of the infringement procedure and refer the three Member States to the Court of Justice of the EU."European Commission - Press release, Relocation: Commission refers the Czech Republic, Hungary and Poland to the Court of Justice, Brussels, 7 December 2017 http://europa.eu/rapid/press-release_IP-17-5002_en.htm[10-01-2018]

$0^{256}$ Protests at Polish logging of ancient forest, by Natalie Huet, last updated: 01/09/2017

http://www.euronews.com/2017/09/01/europe-environment-justice-protests-at-polish-logging-ofancient-forest [10-01-2018]

${ }^{257}$ POLISH PM SEEKS NEW OPENING WITH EU BUT STICKS TO COURTS OVERHAUL, BY PAWEL SOBCZAK, GABRIELA BACZYNSKA, https://af.reuters.com/article/worldNews/idAFKBN1EY180[10-01-2018]

${ }^{258}$ European Commission - Statement, Statement following the working dinner between President Juncker and Polish Prime Minister Morawieck, Brussels, 9 January 2018 http://europa.eu/rapid/press-release_STATEMENT-18-86_en.htm[10-01-2018] 
consultation, they have not been able to act effectively against it.259 The EU would obviously opposed if a Member State manipulates, deceives, misleads the population about the EU decisions and acts, but the EU institutions can hardly do anything about it. It cannot be emphasised too strongly that these are well-planned and quickly executed actions and the EU can only respond very slowly and cannot give immediate effective response. Although the general principle of good faith is theoretically binding both for the EU institutions and for the Member States, there are no effective means to enforce it. Although the ECJ has expressed its position in several judgments on the principle of good faith, ECJ can only take action in any matters, settle legal disputes between national governments and EU institutions, if it is referring the court competences.260In light of all aforementioned, the situation that has emerged as a result of a series of threatening the rule of law might rightly be called a trap situation.

Symbolically might be described this situation as "an asymmetric warfare"between EU and someMember States.On one side is the EU that can only acts within its limits set out in the Treaties, using its traditional tools, on the other side are some Member States that using unconventional

${ }^{259}$ The seven survey questions - each one essentially asking "Do you agree with this?" about the supposed Soros plan.

1. George Soros wants to convince Brussels to resettle at least one million immigrants from Africa and the Middle East annually on the territory of the European Union, including Hungary as well.

2. George Soros, together with leaders in Brussels, also plan to have the member states of the E.U., including Hungary, take down the border protection fences and open the borders for immigrants.

3. It is part of the Soros plan that Brussels redistributes immigrants gathered in Western European countries on a mandatory basis, referring in particular to Eastern European countries. Hungary would be required to take part in this as well.

4. Based on the Soros plan, Brussels should require every member state, including Hungary, to pay 9 million HUF (Hungarian currency equivalent to around $\$ 30,000$ ) in mandatory state aid for every immigrant.

5. George Soros would also like to see migrants receive lighter sentences for the crimes they commit.

6. The goal of the Soros plan is to diminish the importance of the language and culture of European countries to make the integration of illegal immigrants happen sooner.

7. It is part of the Soros plan to launch political attacks on countries objecting to immigration and impose strict penalties on them."

Government launches new anti-Soros campaign, Wednesday, September 27, 2017, 15:35

https://bbj.hu/politics/government-launches-new-anti-soros-campaign_139373[10-01-2018]

260 "In that regard, the Court would point out that the principle of good faith is a rule of customary international law, the existence of which has been recognised by the Permanent Court of International Justice established by the League of Nations (see the judgment of 25 May 1926, German interests in Polish Upper Silesia, CPJI, Series A, No 7, pp. 30 and 39), and subsequently by the International Court of Justice and which, consequently, is binding in this case on the Community and on the other participating partners."[...]It should also be noted that the principle of good faith is the corollary in public international law of the principle of protection of legitimate expectations which, according to the case-law, forms part of the Community legal order (Case T115/94 Opel Austria v Council [1997] ECR II-39, paragraph 93).

JUDGMENT OF 17. 1. 2007 — CASE T-231/04 
rhetoric and tactics tools.261 The EU is trying to cope with this situation, however for the time being the EU cannot use the same effective tools as in those cases where that jeopardize the functioning of the internal market. It is clear that in the cases of the alleged infringement of the rule of law, the EU has only limited and not effective toolbar.262

Maybe a serious restraint could be the differentiated allocation of EU resources, but the current rules rightfully do not allow the retrospective amendments of the rules.263 Commission President Junkers did not even considered it applicable. At the same time, as the negotiations on anew seven-year budget so-called Multiannual financial framework (MFF) post 2020will begin where the Member States will decide which Member States get what out of the EU budget; a new situation arises. Since both Poland and Hungary are actually the largest net beneficiaries of the EU budget, their primary interest is to engage in successful negotiations. To this end, both country will necessarily need to find supporting partners and allies, which will not be easy in the present atmosphere. Replacing a new image will surely come to fruition for this purpose, but changing only the image does not go far enough. The procedure under Article 7 is a slow process whose results would be difficult to predict. "The sword of Damocles is hovering over the head of Hungary", and in spring of 2018 the European Parliament may even intensify the mechanism under Article 7 against Hungarian government. Since there will be elections in both countries (Hungary has parliamentary election in spring 2018, PiS faces local elections in late 2018 and legislative and presidential ballots in 201920 ), until this has been completed, a substantive change in this area cannot be expected. There is still bargaining and the maintaining of the double speech of the governments concerned; in the country emphasizing the protection of sovereignty, hard EU criticisms, as if the EU was a counter party or an enemy organization, by omitting the benefits of EU membership while at the same time widening the EU's operational difficulties (which is partly the result of the not constructive behaviour of these countries) and using a more lenient voice in the EU institutions and forums. Under the EU law the protection against the arbitrarily interpretation of the rules is not allowed, the European Court of Justice alone has the right to formulate a credible position. Even today, special attention must be given to the decision of the ECJ, which stated in 1986 that “...[T]he European Economic Community is a Community based on the rule of law inasmuch neither its Member States nor its institutions can avoid a review of the question whether the measures adopted by them are in conformity with the basic constitutional charter the Treaty" 264Nevertheless, currently, the EU has no effective means to combat the tactics represented by Poland and Hungary. After the European Commission launched an unprecedented Article 7 sanctions procedure against Poland in December 2017 , it seems that the EU has come out of its inability to do so, however, it can be justly be claimed, this procedure is a very slow and has doubtful outcome. The only solution would be

${ }^{261}$ The term was used by Andrew J. R. Mack's 1975 article "Why Big Nations Lose Small Wars" in World Politics, in which "asymmetric" referred simply to a significant disparity in power between opposing actors in a conflict.

http://www.dictionary.com/browse/asymmetric-warfare[10-01-2017]

262Poland and Hungary, along with the Czech Republic, have refused to take in asylum seekers despite an EU decision in 2015 to do so, and as a result the EU commission has referred the countries to the EU's top court in December.

${ }^{263}$ TYING EU FUNDS TO POLITICS COULD BE DOUBLE-EDGED, BY ESZTER

ZALAN, BRUSSELS, 24. OCT 2017, 17:56

https://euobserver.com/political/139617 [10-01-2017]

${ }^{264} \mathrm{ECJ}$, The Green Party v. Parliament, 1986

http://eur-lex.europa.eu/legal-content/EN/TXT/?uri=ecli:ECLI:EU:C:1986:166 [10-01-2018] 
redrafting the Treaties in such a way that it would have the power to act effectively against obstructing the rule of law, and that it could be prevented. A much faster and more flexible mechanism would be needed to respond effectively to potential hazards, to the threats that couldjeopardizingthe rule of law. To do this, first of all, there is a need for political will to persuade the concept of the rule of law to be more delimited. As long as the rule of law is susceptible for several interpretation, it is difficult to tackle those infringements. One can certainly conclude that violations of the rule of law standards, weaken the whole Union, and have a negative impact on their cohesion and on its future. 